\title{
Impact of thermo-sonication on antioxidant potential in juices of selected citrus varieties
}

\author{
Muhammad Bilal Shahid1*, Muhammad Nadeem¹, Mian Anjum Murtaza', Lala Rukh1, Amal Shaukat',2, \\ Mian Nadeem Riaz ${ }^{3}$ \\ ${ }^{1}$ Institute of Food Science and Nutrition, University of Sargodha, Pakistan, 40100 \\ ${ }^{1,2}$ Department of Food Science \& Technology, University of Central Punjab, Lahore, Pakistan \\ ${ }^{3}$ Process Engineering R \& D Center, Graduate Faculty, Nutrition and Food Science Dept. Texas A\&M University, USA
}

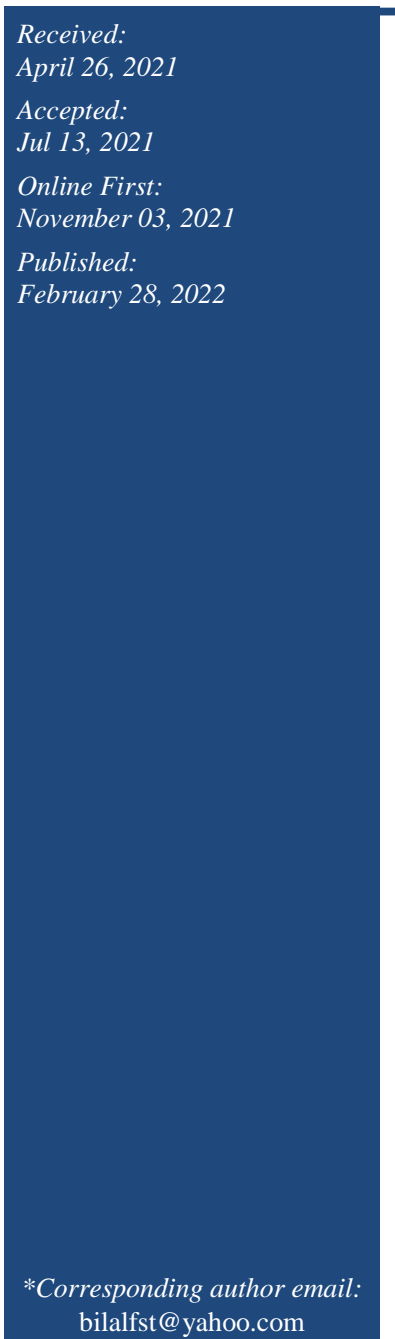

\section{Abstract}

Citrus is known as a good source of valuable bioactive components and vitamins. In fruit juices, thermal treatments such as pasteurization are usually used for inactivation of enzymes and for destruction of microorganisms. Thermo-sonication is combination of heat ( 37 to $75{ }^{\circ} \mathrm{C}$ ) with ultra-sonication treatment has high efficiency for inactivation of microbes and enzymes. The present study aims to develop a new processing technique for citrus juice to improve its functional properties. Variety Succari excelled in terms of average fruit diameter and weight and the maximum number of segments found in Feutrell's Early. The highest acidity value was observed in T0 $(0.251 \pm 0.008 \%)$ and the lowest in T1 $(0.147 \pm 0.002 \%)$ juice of Kinnow. Acidity value was decreased by application of pasteurization. Total phenolic contents of Musambi juice showed significant increase in thermo-sonicated and sonicated juice in comparison to non-sonicated juice. The increase was high in T4 $(458.89 \pm 6.72$ $\mu \mathrm{g} / \mathrm{mL}$ of GAE) and T5 (450.37 $\pm 9.83 \mu \mathrm{g} / \mathrm{mL}$ of GAE). Antioxidant activity showed significant increase in thermo-sonicated and sonicated juice. The increase was high in T5 $(1,103.20 \pm 9.94 \mu \mathrm{g} / \mathrm{mL}$ of ascorbic acid equivalent) and T5 $(1,110.74 \pm 23.67$ $\mu \mathrm{g} / \mathrm{mL}$ of AAE) in juice of Kinnow. Total plate count showed significant reduction in thermo-sonicated (T4) and in combined treatment of chemically preserved and pasteurized (T3) juice in comparison to sonicated (T5) and non-sonicated (T1 and T2) juice. The minimum decrease of total plate count was found in juice of Feutrell's Early while maximum reduction was checked in the juice of Musambi during storage.

Keywords: Citrus; physical properties; acidity; total phenols; anti-oxidant; AAE (Ascorbic acid equivalent); GAE (Gallic acid equivalent)

\section{How to cite this:}

Shahid MB, Nadeem M, Murtaza MA, Rukh L, Shaukat A and Riaz MN, 2022. Impact of thermo-sonication on antioxidant potential in juices of selected citrus varieties. Asian J. Agric. Biol. 2022(2): 202104174. DOI: https://doi.org/10.35495/ajab.2021.04.174

This is an Open Access article distributed under the terms of the Creative Commons Attribution 3.0 License. (https://creativecommons.org/licenses/by/3.0), which permits unrestricted use, distribution, and reproduction in any medium, provided the original work is properly cited.

\section{Introduction}

Fruits are healthy food which provides minerals, vitamins and dietary fiber (Rocha and Morais, 2003). The genus citrus belonging to the family Rutaceae consists of almost 40 types and is considered as a 
world's important crop and consumed in both of its form, as fresh fruit and as well as juice, because it has valuable nutritional value and unique flavor. Some juices are recommended to be the part of human diet because of having functional components like natural antioxidants and vitamin $\mathrm{C}$ which has the capability to inhibit the formation of different clinical circumstances like heart diseases and certain cancers (Khosa et al., 2011). Citrus fruit juices have significant quantity of phenolics, carotenoids and flavonoids and their calculable variations in the proportions occurs because of agro-climatic conditions and origins (Khosa et al., 2011). Citrus includes anti-oxidants that minimizes the risk of numerous diseases like cardiovascular, certain cancers and arteriosclerosis (Louche et al., 2000). The juice of citrus comprises of phenolic compounds, minerals, amino acids, carbohydrates and proteins etc. Vitamins, minerals and other food components in the citrus fruit has capability to improve weak health rapidly (Karimi et al., 2012).

During marketing and transportation, the perishability of citrus juice can be enhanced by pasteurization. Carotenoids are considered as heat stable during cooking, canning and blanching (Borenstein and Bunnell, 1966), but carotenoid stability differs significantly in foods (Purcell et al., 1969). Previously, it was thought that pasteurization had no effect on the constituents of carotenoids. But during a thermal processing study on fruit and vegetables including citrus juice, conducted by (Lessin et al., 1997) showed a comparatively excessive loss (up to $36 \%$ ) of carotenoids (bcryptoxanthin, a and b carotene) and pro-vitamin A. The juice of citrus is one of the most generally consumed drinks because of its health benefits, unique taste and aroma (Ren et al., 2015).

In thermal processing techniques heat is commonly used for the inactivation of enzymes and also to kill the microbes. Over the last few years, heat processing methods were preferred with the combination of new technological advances. But excessive heat causes different chemical and physical changes which alter the sensory characteristics of food products and minimize the bioavailability of nutrients and their properties (Pereira and Vicente, 2010).

Nowadays, different non-thermal technologies are accessible to achieve the requirement of healthy and natural fruit juices with negligible effect of its natural organoleptic and nutritious characteristics. Common thermal processing methods for fruit juices effects in some nutritious component's loss such as carotenoids (Fratianni et al., 2010) and flavonoids (Igual et al., 2011). There might be the chances of off flavors, darker color and excessive suspended solids (Rutledge, 1996).

Ultrasound technique may also be used for the processing of fruit juices due to several benefits regarding the quality of fruit juices, reduced energy consumption, decreasing processing time, improving shelf life and increased efficiency. Ultrasound presented valuable properties in foodstuff preservation and processing with less working and maintenance costs, less processing times, greater product yields, enhanced quality characteristics and reduction of pathogens (Patist and Bates, 2008). It develops food safety and quality and have chances for developing new products with distinctive properties (Awad et al., 2012). The present project is planned to explore the impact of thermal and nonthermal processing techniques on functional properties of different citrus juices during storage.

\section{Material and Methods}

\section{Purchase of fruits and chemicals}

All the reagents and chemicals were purchased from Fluka Chemical Co. (Buchs, Switzerland) and Merck (Darmstadt, Germany). Citrus varieties were collected from the Citrus Research Institute, Risala No. 5. Sargodha, Pakistan. The research work was carried out at Institute of Food Science and Nutrition, University of Sargodha, Sargodha. Physicochemical characteristics of different varieties of citrus (Musambi, Succari, Feutrell's Early \& Kinnow) were studied. Fruits of each cultivar were picked at the optimum time of maturity. The samples of fruit were collected from all sides of the tree i.e. from top and inside the canopy. Variation in plants and at the farm was also considered.

\section{Physical analysis of fruits}

The sample of 20 fruits were taken to determine the quality characteristics at the optimum time of maturity. Fruit weight (g) was measured by using a digital calibrated scale. The number of segments was counted manually (Cheng, 2008).

\section{Preparation of juice}

After weighing of each fruit, rotary citrus squeezer (MJ-M176P, Panasonic Manufacturing, Berhad, Malaysia) was used to extract the juice. The juice 


\section{Muhammad Bilal Shahid et al.}

was filtered over $0.8 \mathrm{~mm}$ pore size sieve. Juice of each variety $(100 \mathrm{~mL})$ was separated into two equal parts $(50 \mathrm{~mL}$ each) for further analysis.

\section{Juice \%}

Following expression was used to calculate the juice percentage (Khan et al., 2004).

Juice $\%=$ Juice weight (g) / Fruit weight (g) x 100

\section{Chemical preservation}

For chemical preservation, the citrus juice was chemically treated by potassium meta-bisulphite (KMS) at the rate of $750 \mathrm{ppm}$.

\section{Pasteurization of juice}

Pasteurization was done by the method of Dede et al. (2007). Heat treatment given to juice samples (bottles) in water bath at $81{ }^{\circ} \mathrm{C}$ for $90 \mathrm{sec}$ for pasteurization (industrial pasteurization application) (Scalzo et al., 2004). During pasteurization, bottles were continuously stirred for proper heat transfer. Bottles were taken out when the required temperature achieved which was measured by digital temperature probe and then instantly cooled in an ice bath. All measurements and experiments were replicated thrice on separate days.

\section{Ultrasound processing of juice}

The juice obtained from each variety was subjected to ultra-sonication process. The ultrasonic processor (UP400S, Hielscher Ultrasonics GmnH Hielscher USA, Inc.) with 0.5-inch probe was used for sonication. The juice was subjected to ultrasound treatment (pulse duration of $5 \mathrm{~s}$ on and $5 \mathrm{~s}$ off, amplitude level of $80 \%$ and $20 \mathrm{kHz}$ frequency) for 4 $\min$ at $20{ }^{\circ} \mathrm{C}$. The sonication was performed immediately after extraction of fresh juice. The analysis was done in dark. The fresh sample without sonication was used as a control. All juice samples (control or sonicated) were kept at $4{ }^{\circ} \mathrm{C}$ for more experiments.

\section{Chemical analysis of juice Total titratable acidity}

Titratable acidity was determined by titration method with standardized $0.1 \mathrm{~N} \mathrm{NaOH}$ up to $\mathrm{pH} 8.2$. Phenolphthalein as an indicator was used to check the persistent pink color using known volumes of a representative sample of juice. The results were expressed as grams of citric acid per $100 \mathrm{~mL}$ of juice
(AOAC, 2012).

Acidity $\%($ as citric acid $)=$ Titer value $(\mathrm{mL}) \times 0.0064$ $/ 10 \times 100$

\section{Total phenolic contents}

Spectrophotometer (using Folin-Ciocalteu reagent with some modifications) was used for the determination of total phenolic contents (Singleton et al., 1999). Juice sample of known concentration (0.5 $\mathrm{mL}$ ) was mixed with $1 \mathrm{~mL}$ of $10 \%$ Folin-Ciocalteu reagent. The blend was blended well and left it for 6 min. Then $2 \mathrm{~mL}$ of sodium carbonate solution (20\%) was added to that blend. The total phenolic contents were determined at $760 \mathrm{~nm}$ using spectrophotometer after incubation for $60 \mathrm{~min}$ at $30{ }^{\circ} \mathrm{C}$. For calibration curve, standard solution was prepared by using Gallic acid. The results were shown as $\mu \mathrm{g}$ of gallic acid equivalents (GAE) per milligram of sample.

\section{Total antioxidant activity}

For antioxidant capacity determination, citrus fruit juices of all varieties were determined by the technique defined by (Prieto et al., 1999). $0.4 \mathrm{~mL}$ of sample was mixed with $4 \mathrm{~mL}$ of reagent solution (0.6 M Sulfuric Acid $+28 \mathrm{mM}$ Sodium Phosphate $+4 \mathrm{mM}$ Ammonium Molybdate). The absorbance was measured at $695 \mathrm{~nm}$ after incubating for $95 \mathrm{~min}$ at 90 ${ }^{\circ} \mathrm{C}$. Blank solution with reagent and methanol was run and absorbance was measured at the same wavelength. The results were expressed as $\mu \mathrm{g}$ ascorbic acid equivalent (AAE)/mL sample. All experiments were performed in triplicates.

\section{Microbiological analysis}

The citrus juices after different treatments were stored in refrigeration $\left(4 \pm 1{ }^{\circ} \mathrm{C}\right)$ for three months. Juice samples were analyzed for total plate count to check the shelf stability of the juices after every 1.5 month (Rockville and Latimer, 2016). $1 \mathrm{~mL}$ sample (citrus juice) was taken into test tube by sterile pipette and $9 \mathrm{~mL}$ saline solution was added for making dilutions. Decimal dilution was formed by shifting $1 \mathrm{~mL}$ of previous dilution to $9 \mathrm{~mL} .15 \mathrm{~mL}$ of media (pre-cooled to $45^{\circ} \mathrm{C}$ ) was shifted in plates within 15 minutes of time and allowed to solidify. Dilutions were shifted in control plates then mixed sample dilutions and agar medium. Petri dishes were incubated at $35{ }^{\circ} \mathrm{C}$ for 48 hours. All colonies were calculated between 30 and 300 colonies and multiplied by dilution factor. 


\section{Statistical analysis}

The data obtained from chemical assay was subjected to analysis of variance technique and mean values \pm SD were calculated by LSD test at $5 \%$ level of significance. The statistical analyses were performed using Statistix 8.1 software (Analytical Software, Tallahassee, FL, USA).

\section{Results and Discussion}

\section{Physical properties of citrus varieties}

Citrus variety Succari excelled in terms of average fruit diameter $73.46 \pm 1.13 \mathrm{~mm}$ and fruit weight $212.95 \pm 9.30 \mathrm{~g}$ followed by Kinnow $65.05 \pm 1.07 \mathrm{~mm}$, $152.40 \pm 7.83 \mathrm{~g}$. The minimum fruit diameter and weight were observed in Musambi $61.78 \pm 0.66 \mathrm{~mm}$, $127.45 \pm 3.45 \mathrm{~g}$ respectively, and in Feutrell's Early $61.49 \pm 0.71 \mathrm{~mm}, 114.25 \pm 3.75 \mathrm{~g}$ (Table 01).

The maximum number of segments found in Feutrell's Early $11.20 \pm 0.22$ and Succari $10.75 \pm 0.22$ followed by Kinnow $10.40 \pm 0.18$ while minimum number of segments were recorded in Musambi $10.10 \pm 0.16$. The maximum juice $51.5 \%$ was observed in Succari while the minimum juice $49.6 \%$ was obtained by Musambi.

Qureshi et al. (2020) studied the characteristics of indigenous varieties of mango (Mangifera indica L.). They found significant differences among varieties of mango (Sindhri, Anwar Ratol, Langra, Gulab Khas, Chaunsa, Sunehri, Dosehri and Desi). They found the maximum fruit weight in Sindhri $407.6 \mathrm{~g}$ and Chaunsa $255.9 \mathrm{~g}$ while minimum fruit weight in Desi and Anwar Ratol. The maximum pulp $73.28 \%$ and edible to non-edible ratio 4.83 was observed in variety Sindhri. They described that some varieties of mango had high quantity of peel while some had low peel weight.

\section{Chemical analysis of citrus juices}

Citrus Juices was stored in refrigerator at $4 \pm 1{ }^{\circ} \mathrm{C}$ and analyzed for acidity.

\section{Acidity of citrus juices}

Acidity showed (Table-2) significant rise in all the samples (thermo-sonicated and sonicated juice and non-sonicated juice). T0 (control) showed the highest value of acidity and T1 (chemically treated) showed the lowest value of acidity among all the citrus juices but the effect was significant among treatments. The highest acidity value was observed in T0 $0.251 \pm 0.008 \%$ and lowest value in T1 $0.147 \pm 0.002$ $\%$ in the juice of Kinnow (Table-3 and Figure-1). The sonication alone has high acidity value T5: $0.082 \pm 0.004 \%$ as compare to thermos-sonication $\mathrm{T} 4$ $0.081 \pm 0.002 \%$ in the juice of Musambi (Table 3). Acidity value decreases by the implementation of pasteurization T3 $0.074 \pm 0.002 \%$ as compare to control T0 0.088 $\pm 0.008 \%$ (Table-3). Similar trend in acidity was observed in juices of other citrus varieties.

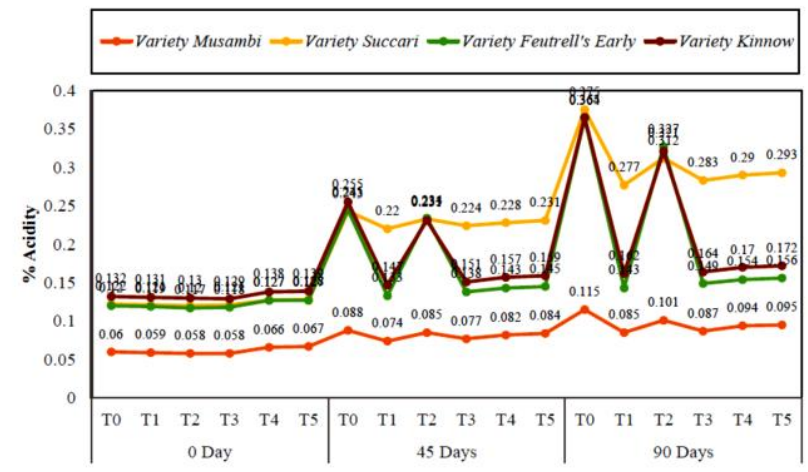

Figure-1. Comparison of means (Treatment $x$ Days $x$ Variety) for acidity (\%)

The minimum increase of acidity was in the juice of Succari while the maximum increase was in the juice of Musambi during storage (Table-2). The acidity value of juices of Musambi, Succari, Feutrell's Early and Kinnow increased significantly during storage of 90 days. The acidity gradually increased with the passage of time. The lowest value of acidity in fresh Musambi juice $0.062 \pm 0.003 \%$ was found at start of storage. However, it increased significantly at 90 days of storage $0.100 \pm 0.005 \%$ (Table-2). The increase in the acidity might be due to rupturing of cell wall and decrease in the $\mathrm{pH}$.

Qureshi et al. (2020) have checked the influence of ultrasound on the functional characteristics of indigenous varieties of mango (Mangifera indica L.). They ultrasonic activity on acidity of mango pulp was found prominent difference. They found highest 1.36 acidity in the pulp (without US treatment) from Desi however pulp from Chaunsa displayed the 0.26 lowest value. They demonstrated that acidity of pulp was increased significantly after $4 \mathrm{~min}$ of US treatment whereas additional treatment altered the values non-significantly. 
Muhammad Bilal Shahid et al.

Table-A: Treatment plan

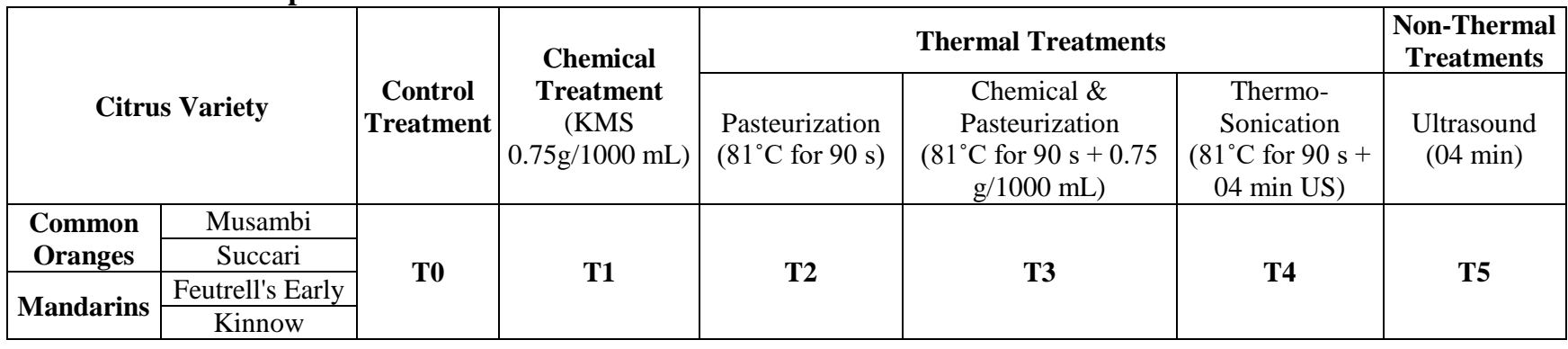

Table-1: Physical analysis of different citrus varieties (Means \pm SE) for fruit diameter (mm), fruit wt. (g), no. of segments and juice $(\mathrm{ml})$.

\begin{tabular}{|c|c|c|c|c|c|}
\hline Variety & Musambi & Succari & Feutrell's Early & Kinnow & Means \\
\hline Fruit Diameter (mm) & $61.78 \pm 0.66^{\mathrm{D}}$ & $73.46 \pm 1.13^{\mathrm{A}}$ & $61.49 \pm 0.71^{\mathrm{C}}$ & $65.05 \pm 1.07^{\mathrm{B}}$ & $65.44 \pm 0.78$ \\
\hline Fruit Wt. (g) & $127.45 \pm 3.45^{\mathrm{C}}$ & $212.95 \pm 9.30^{\mathrm{A}}$ & $114.25 \pm 3.75^{\mathrm{D}}$ & $152.40 \pm 7.83^{\mathrm{B}}$ & $151.76 \pm 5.72$ \\
\hline No. of Segments & $10.10 \pm 0.16^{\mathrm{D}}$ & $10.75 \pm 0.22^{\mathrm{B}}$ & $11.20 \pm 0.22^{\mathrm{A}}$ & $10.40 \pm 0.18^{\mathrm{C}}$ & $10.61 \pm 0.10$ \\
\hline Juice (ml) & $63.00 \pm 2.34^{\mathrm{C}}$ & $104.50 \pm 2.94^{\mathrm{A}}$ & $56.50 \pm 1.80^{\mathrm{D}}$ & $65.00 \pm 1.27^{\mathrm{B}}$ & $72.25 \pm 3.16$ \\
\hline
\end{tabular}

Means having similar letters in a column or in a row are statistically non-significant $(\mathrm{P}>0.05)$

Table-2: Comparison of means \pm SE (Days $x$ Variety) for acidity $(\%)$

\begin{tabular}{|c|c|c|c|c|c|}
\hline \multirow{2}{*}{ Days } & \multicolumn{4}{|c|}{ Variety } & Means \\
\cline { 2 - 6 } & Musambi & Succari & Feutrell's Early & Kinnow & Days x Variety \\
\hline 0 Day & $0.062 \pm 0.003 \mathrm{~J}$ & $0.123 \pm 0.003 \mathrm{G}$ & $0.122 \pm 0.003 \mathrm{IG}$ & $0.133 \pm 0.003 \mathrm{~F}$ & $0.1099 \pm 0.003 \mathrm{C}$ \\
\hline 45 Days & $0.082 \pm 0.003 \mathrm{I}$ & $0.230 \pm 0.002 \mathrm{~B}$ & $0.173 \pm 0.003 \mathrm{E}$ & $0.183 \pm 0.002 \mathrm{D}$ & $0.1670 \pm 0.003 \mathrm{~B}$ \\
\hline 90 Days & $0.100 \pm 0.005 \mathrm{H}$ & $0.304 \pm 0.007 \mathrm{~A}$ & $0.216 \pm 0.006 \mathrm{C}$ & $0.226 \pm 0.005 \mathrm{~B}$ & $0.2105 \pm 0.003 \mathrm{~A}$ \\
\hline Means & $0.080 \pm 0.002 \mathrm{D}$ & $0.220 \pm 0.002 \mathrm{~A}$ & $0.170 \pm 0.002 \mathrm{C}$ & $0.181 \pm 0.002 \mathrm{~B}$ & \\
\hline
\end{tabular}

Means having similar letters in a column or in a row are statistically non-significant $(\mathrm{P}>0.05)$. Within box means express interaction means.

Table-3: Comparison of means \pm SE (Treatment $x$ Variety) for acidity (\%)

\begin{tabular}{|c|c|c|c|c|c|}
\hline \multirow{2}{*}{ Treat. } & \multicolumn{4}{|c|}{ Variety } & Means \\
\cline { 2 - 6 } & Musambi & Succari & Feutrell's Early & Kinnow & Treat x Variety \\
\hline T0 & $0.088 \pm 0.008 \mathrm{I}$ & $0.247 \pm 0.011 \mathrm{~A}$ & $0.243 \pm 0.009 \mathrm{~A}$ & $0.251 \pm 0.008 \mathrm{~A}$ & $0.207 \pm 0.005 \mathrm{~A}$ \\
\hline T1 & $0.072 \pm 0.001 \mathrm{~J}$ & $0.206 \pm 0.001 \mathrm{E}$ & $0.132 \pm 0.001 \mathrm{H}$ & $0.147 \pm 0.002 \mathrm{FG}$ & $0.139 \pm 0.004 \mathrm{D}$ \\
\hline T2 & $0.081 \pm 0.003 \mathrm{IJ}$ & $0.222 \pm 0.004 \mathrm{BC}$ & $0.226 \pm 0.004 \mathrm{~B}$ & $0.227 \pm 0.004 \mathrm{~B}$ & $0.190 \pm 0.004 \mathrm{~B}$ \\
\hline T3 & $0.074 \pm 0.002 \mathrm{SJ}$ & $0.209 \pm 0.002 \mathrm{DE}$ & $0.135 \pm 0.002 \mathrm{H}$ & $0.148 \pm 0.003 \mathrm{FG}$ & $0.142 \pm 0.004 \mathrm{D}$ \\
\hline T4 & $0.081 \pm 0.002 \mathrm{IJ}$ & $0.215 \pm 0.001 \mathrm{C}-\mathrm{E}$ & $0.141 \pm 0.001 \mathrm{GH}$ & $0.155 \pm 0.002 \mathrm{~F}$ & $0.148 \pm 0.004 \mathrm{C}$ \\
\hline T5 & $0.082 \pm 0.004 \mathrm{IJ}$ & $0.217 \pm 0.004 \mathrm{~B}-\mathrm{D}$ & $0.143 \pm 0.004 \mathrm{GH}$ & $0.157 \pm 0.005 \mathrm{~F}$ & $0.150 \pm 0.004 \mathrm{C}$ \\
\hline
\end{tabular}

Means having similar letters in a column or in a row are statistically non-significant $(\mathrm{P}>0.05)$. Within box means express interaction means.

$T_{0}=$ Control (citrus juice), $T_{1}=$ preservative juice $(0.075 \% \mathrm{KMS}), \mathrm{T}_{2}=$ Pasteurization $81{ }^{\circ} \mathrm{C}$ for $90 \mathrm{sec}, \mathrm{T}_{3}=$ preservative $(0.075 \% \mathrm{KMS})$ \& $90 \mathrm{sec}$ Pasteurization $81^{\circ} \mathrm{C}, \mathrm{T}_{4}=04$ mints Ultrasound \& 90 sec Pasteurization $81^{\circ} \mathrm{C}, \mathrm{T}_{5}=04$ mints Ultrasound

\section{Total phenolic content (TPC) of citrus juices}

Total phenolic contents of Musambi juice showed (Table-5 and Figure-2) prominent increase in thermosonicated and sonicated juice in comparison to nonsonicated juice. The maximum increase $458.89 \pm 6.72$ $\mu \mathrm{g} / \mathrm{mL}$ was observed in $\mathrm{T} 4$ and $450.37 \pm 9.83 \mu \mathrm{g} / \mathrm{mL}$ of gallic acid equivalent $\mathrm{T} 5$ as compare to control $317.85 \pm 25.02 \mu \mathrm{g} / \mathrm{mL}$ of gallic acid equivalent. Similar trend in total phenolic content was observed in juices of other citrus varieties. 


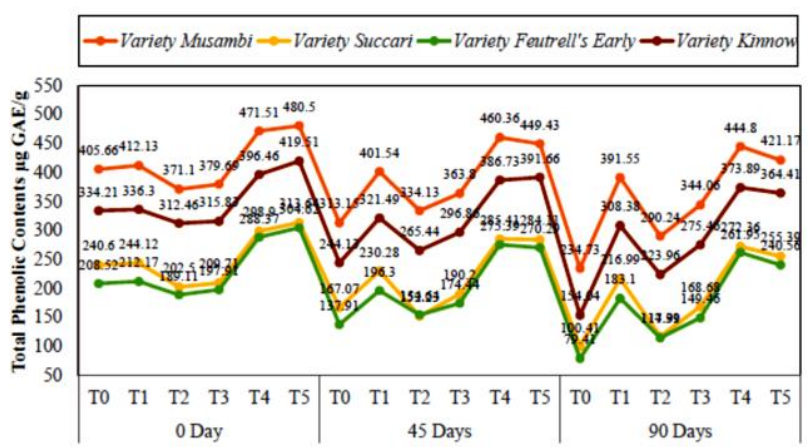

Figure-2. Comparison of means (Treatment $x$ Days $x$ Variety) for total phenolic contents $\mu \mathrm{g}$ GAE/g

Table-4: Comparison of means \pm SE (Days $x$ Variety) for total phenolic contents (TPC) ( $\mu \mathrm{g} \mathrm{GAE} / \mathrm{g})$

\begin{tabular}{|c|c|c|c|c|c|}
\hline \multirow{2}{*}{ Days } & \multicolumn{4}{|c|}{ Variety } & Means \\
\cline { 2 - 6 } & Musambi & Succari & $\begin{array}{c}\text { Feutrell's } \\
\text { Early }\end{array}$ & Kinnow & $\begin{array}{c}\text { Days x } \\
\text { Variety }\end{array}$ \\
\hline \multirow{2}{*}{ Day } & 420.10 & 251.58 & 233.45 & 352.46 & 314.40 \\
& $\pm 10.72 \mathrm{~A}$ & $\pm 10.37 \mathrm{~F}$ & $\pm 11.26 \mathrm{G}$ & $\pm 10.23 \mathrm{C}$ & $\pm 7.43 \mathrm{~A}$ \\
\hline $\mathbf{4 5}$ & 387.07 & 218.22 & 201.49 & 317.72 & 281.12 \\
Days & $\pm 13.71 \mathrm{~B}$ & $\pm 12.97 \mathrm{H}$ & $\pm 13.19 \mathrm{I}$ & $\pm 13.76 \mathrm{D}$ & $\pm 7.81 \mathrm{~B}$ \\
\hline $\mathbf{9 0}$ & 354.43 & 188.52 & 171.58 & 283.36 & 249.47 \\
Days & $\pm 18.08 \mathrm{C}$ & $\pm 15.98 \mathrm{I}$ & $\pm 15.89 \mathrm{~J}$ & $\pm 18.84 \mathrm{E}$ & $\pm 8.55 \mathrm{C}$ \\
\hline Means & 387.20 & 219.44 & 202.17 & 317.84 & \\
& $\pm 8.99 \mathrm{~A}$ & $\pm 8.32 \mathrm{C}$ & $\pm 8.44 \mathrm{D}$ & $\pm 9.19 \mathrm{~B}$ & \\
\hline
\end{tabular}

Means having similar letters in a column or in a row are statistically non-significant $(\mathrm{P}>0.05)$. Within box means express interaction means.

The minimum decrease of total phenolic contents was observed in the juice of Musambi $15.63 \%$ while the maximum reduction was observed in the juice of Feutrell's Early $26.50 \%$ during storage (Table 4). The total phenolic contents of juices of Musambi, Succari, Feutrell's Early and Kinnow significantly decreased during storage of 90 days. The maximum increase in total phenolic content has been observed in juice of Musambi while minimal increase was observed in juice of Feutrell's Early (Table 4). The total phenolic contents gradually decreased during storage. The maximum value of total phenolic content in fresh Musambi juice $420.10 \pm 10.72 \mu \mathrm{g} / \mathrm{mL}$ of gallic acid equivalent was found at start of storage. However, it decreased significantly at 90 days of storage $354.43 \pm 18.08 \mu \mathrm{g} / \mathrm{mL}$ of gallic acid equivalent. The combined effect of pasteurization and sonication shows better retention of total phenolic contents in juices of Musambi, Succari, Feutrell's Early and Kinnow as well as during the storage period of 90 days as compare to that of which were preserved chemically, pasteurized or sonicated alone. Phenolic components are the essential components of fruits due to their powerful antioxidant behavior. Phenolic components in fruits plays a vital role in organoleptic properties such as color, flavor and bitterness. That's why phenolics are considered as the quality parameter for fruits and its products (Kreutzmann et al., 2008; Zhang et al., 2005; Naczk and Shahidi, 2003).

Table-5: Comparison of means \pm SE (Treatment $x$ Variety) for total phenolic contents (TPC) $(\mu \mathrm{g} \mathrm{GAE} / \mathrm{g})$

\begin{tabular}{|c|c|c|r|r|r|}
\hline \multirow{2}{*}{ Treat. } & \multicolumn{4}{|c|}{ Variety } & Means \\
\cline { 2 - 6 } & Musambi & Succari & $\begin{array}{l}\text { Feutrell } \\
\text { 's Early }\end{array}$ & Kinnow & $\begin{array}{r}\text { Treat x } \\
\text { Variety }\end{array}$ \\
\hline \multirow{2}{*}{ T0 } & 317.85 & 169.36 & $141.95 \pm$ & $244.13 \pm$ & $218.32 \pm$ \\
& $\pm 25.02 \mathrm{D}$ & $\pm 20.42 \mathrm{IJ}$ & $18.78 \mathrm{~K}$ & $26.23 \mathrm{G}$ & $11.23 \mathrm{E}$ \\
\hline \multirow{2}{*}{ T1 } & 401.74 & 230.46 & $197.19 \pm$ & $322.06 \pm$ & $287.86 \pm$ \\
& $\pm 5.50 \mathrm{~B}$ & $\pm 5.08 \mathrm{G}$ & $4.68 \mathrm{H}$ & $5.32 \mathrm{D}$ & $9.39 \mathrm{~B}$ \\
\hline \multirow{2}{*}{ T2 } & 331.82 & 157.35 & $152.91 \pm$ & $267.28 \pm$ & $227.34 \pm$ \\
& $\pm 12.06 \mathrm{D}$ & $\pm 12.59 \mathrm{JK}$ & $11.26 \mathrm{JK}$ & $13.22 \mathrm{~F}$ & $9.43 \mathrm{D}$ \\
\hline \multirow{2}{*}{ T3 } & 362.51 & $189.53 \pm 6.40 \mathrm{HI}$ & $173.94 \pm$ & $296.05 \pm$ & $255.51 \pm$ \\
& $\pm 6.64 \mathrm{C}$ & & $7.47 \mathrm{IJ}$ & $6.59 \mathrm{E}$ & $8.99 \mathrm{C}$ \\
\hline \multirow{2}{*}{ T4 } & 458.89 & $285.56 \pm 4.86 \mathrm{E}$ & $275.24 \pm$ & $385.69 \pm$ & $351.34 \pm$ \\
& $\pm 6.72 \mathrm{~A}$ & $\mathrm{~F}$ & $5.64 \mathrm{EF}$ & $4.67 \mathrm{~B}$ & $9.65 \mathrm{~A}$ \\
\hline \multirow{2}{*}{ T5 } & 450.37 & $284.38 \pm 9.58 \mathrm{E}$ & $271.82 \pm$ & $391.86 \pm$ & $349.61 \pm$ \\
& $\pm 9.83 \mathrm{~A}$ & F & $10.39 \mathrm{~F}$ & $8.84 \mathrm{~B}$ & $9.94 \mathrm{~A}$ \\
\hline
\end{tabular}

Means having similar letters in a column or in a row are statistically non-significant $(\mathrm{P}>0.05)$. Within box means express interaction means.

$T_{0}=$ Control (citrus juice), $T_{1}=$ preservative juice (0.075\% KMS), $T_{2}=$ Pasteurization $81{ }^{\circ} \mathrm{C}$ for $90 \mathrm{sec}$, $T_{3}=$ preservative $(0.075 \% \quad \mathrm{KMS}) \quad \& \quad 90 \mathrm{sec}$ Pasteurization $81{ }^{\circ} \mathrm{C}, T_{4}=04$ mints Ultrasound \& 90 sec Pasteurization $81{ }^{\circ} \mathrm{C}, T_{5}=04$ mints Ultrasound

Nadeem et al. (2018) checked that effect of ultrasound and chemical treatment on total phenolic content on carrot-grape juice blend during storage. They found that sonicated juice blend showed significant rise in the total phenolic contents.

Kaur and Aggarwal (2015) checked the effect of thermal processing and chemical preservation on storage stability of tomato juice. They found total phenolic content $47.39-47.87 \mathrm{mg} / 100 \mathrm{~g}$ respectively. The chemically preserved juice showed the better total phenolic content retention than thermally treated samples. The decrease was observed in storage period of 3, 6 and 9 months of total polyphenol content of tomato juices.

The results of this study were in favor of research conducted on kasturi lime juice (Bhat et al., 2011). The significant increase in the total phenolic contents thought to be due the production of cavitation by the 
distraction of cell wall that causes the release of some chemically bound total phenolic contents and eventually increase their availability in the juice. The bubbles are formed due to the creation of hydroxal radicals by the implementation of sonication treatment, increased the availability of total phenolic content in citrus juice. Enhancement in the activity of polyphenolic oxidase might be the reason for increase in total phenolic contents.

\section{Total antioxidant activity of citrus juices}

Antioxidant activity of Kinnow showed (Table-7 and Figure-3) significant difference in thermo-sonicated and sonicated juice in comparison to non-sonicated juice. The increase was maximum in $\mathrm{T} 4$ $1,103.20 \pm 9.94 \mu \mathrm{g} / \mathrm{mL}$ and T5 $1,110.74 \pm 23.67 \mu \mathrm{g} / \mathrm{mL}$ respectively in comparison to control $929.61 \pm 38.10$ $\mu \mathrm{g} / \mathrm{mL}$ of ascorbic acid equivalent. Similar trend in antioxidant activity was observed in juices of other citrus varieties (Table-7).

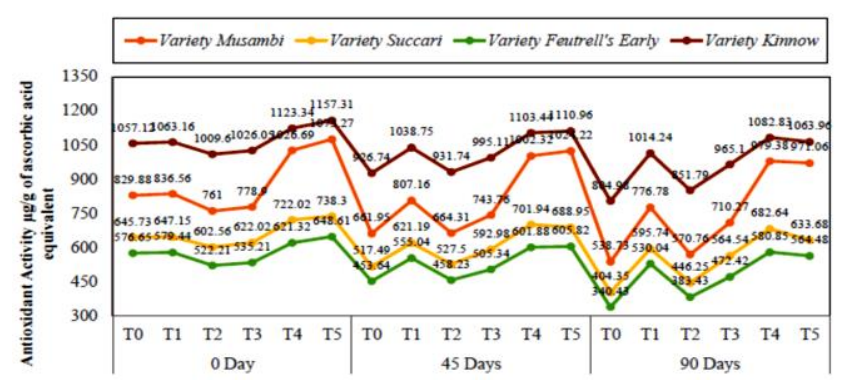

Figure-3. Comparison of means (Treatment $x$ Days $x$ Variety) for total antioxidant activity (TAA)

The minimum decrease of antioxidant activity 10.16 $\%$ was observed in the juice of Kinnow while the maximum reduction $17.56 \%$ was observed in the juice of Feutrell's Early during storage (Table-6). The antioxidant activity of juices of Musambi, Succari, Feutrell's Early and Kinnow significantly decreased during storage of 90 days. The maximum overall rise in antioxidant activity has been found in juice of kinnow while minimal increase was observed in juice of Feutrell's Early (Table-6). The antioxidant activity gradually decreased with the passage of time. The maximum value of antioxidant activity in fresh Kinnow juice $1,072.76 \pm 15.40 \mu \mathrm{g} / \mathrm{mL}$ of ascorbic acid equivalent was found at start of storage. However, it decreased significantly $963.81 \pm 26.89 \mu \mathrm{g} / \mathrm{mL}$ of ascorbic acid equivalent at 90 days of storage. The combined effect of pasteurization and sonication shows better retention of antioxidant activity in juices of Musambi, Succari, Feutrell's Early and Kinnow as well as during the storage period of 90 days as compare to that of which are preserved chemically, pasteurized or sonicated alone.

Ultra-sonication disrupts the bound antioxidants for example ascorbic acid and phenolic contents which lead to the increased total antioxidant activity. Additionally, ultrasonic technique inactivates enzymes, for instance, polyphenol oxidases which are responsible for enzymatic browning leading to enhanced total antioxidant activity values. The samples which have high number of polyphenolic compounds has more antioxidant capacity. Sonication plays significant role in enhancing the total antioxidant activity of citrus juice by increasing its phenolics.

Nadeem et al. (2018) checked that effect of ultrasound and chemical treatment on antioxidant properties on carrot-grape juice blend during storage. They found the significant difference in total antioxidant activity, as sonicated samples show more antioxidant activity as compare to non-sonicated samples. During storage the prominent difference were observed. From day 1 to 90 , the total antioxidant activity decreased of all treated samples significantly. The highest antioxidant was observed in $6 \mathrm{~min}$ ultrasonication treatment $792 \mathrm{mg} / 100 \mathrm{~mL}$ Juice while lowest antioxidant was observed in control $511 \mathrm{mg}$ equivalent of Trolox/100 mL Juice.

Kaur and Aggarwal (2015) described that the antioxidants inhibits the formation of polymerization chain which might be occur due to the free radicals and other subsequent oxidizing reactions which ultimately reduces the oxidation process. According to their results, percent antioxidant activity for samples on the day of preparation to 06 months were 45.77 to 41.92 percent respectively. They found the non-significant $(\mathrm{p} \leq 0.05)$ decrease in antioxidant activity during storage period of 6 months.

\section{Total plate count of citrus juices}

Total plate count of Feutrell's Early juice showed (Table-9 and Figure-4) significant reduction in thermo-sonicated (T4) and in combination chemically preserved and pasteurized (T3) juice in comparison to sonicated (T5) and non-sonicated (T1 and T2) juice. This decrease was maximum in T3 1.56 $\pm 0.010 \log 10$ $\mathrm{cfu} / \mathrm{mL}$ and T4 $1.66 \pm 0.019 \quad \log 10 \quad \mathrm{cfu} / \mathrm{mL}$ respectively as compared to control $2.16 \pm 0.095 \log 10$ $\mathrm{cfu} / \mathrm{mL}$, chemically preserved $1.84 \pm 0.040 \log 10 \mathrm{cfu} /$ $\mathrm{mL}$ and pasteurized $1.78 \pm 0.03 \log 10 \mathrm{cfu} / \mathrm{mL}$. Similar trend in total plate count was observed in 
juices of other citrus varieties. The maximum overall decrease in total plate count has been found in juice of Musambi while minimal decrease was observed in juice of Feutrell's Early (Table-8).

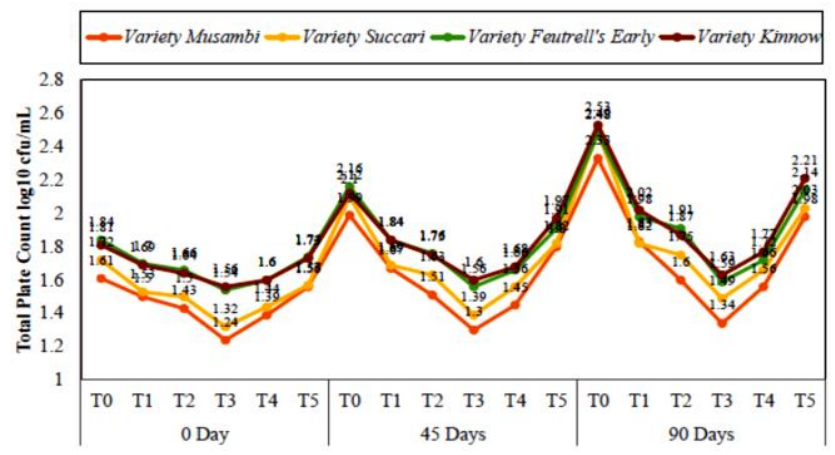

Figure-4. Comparison of means (Treatment $x$ Days $x$ Variety) for total plate count $\mathrm{cfu} / \mathrm{mL}$

The total plate count of juices of Musambi, Succari, Feutrell's Early and Kinnow significantly increased during storage of 90 days. Total plate count gradually increased during storage. The maximum value of total plate count in fresh Musambi juice 1.46 \pm 0.030 $\log 10 \mathrm{cfu} / \mathrm{ml}$ was found at start of storage. However, it increased significantly $1.77 \pm 0.079 \log 10 \mathrm{cfu} / \mathrm{ml}$ at 90 days of storage. The combined effect of pasteurization and chemical preservation and also thermos-sonication shows better reduction of total plate count in juices of Musambi, Succari, Feutrell's Early and Kinnow as well as during the storage period of 90 days as compare to control or sonicated samples alone. The better reduction in total plate count might be due to the implementation of combined treatment of heat and ultrasonication as some microbes are sensitive to heat and killed by the heat treatment.

Zou and Jiang (2016) sonicated carrot juice for 20, 40 and 60 minutes and examined the microbial load in comparison to non-sonicated juice sample. They have observed significant decrease in total plate count of sonicated carrot juice as compared to blank. The maximum reduction in total plate count of carrot juice was noticed in 60 minutes sonicated juice as compared to control.

Abid et al. (2014) studied the thermo-sonication as a potential quality enhancement technique of apple juice. They have observed the impact of thermo-sonication on total plate count. They illustrated that the total plate count is highly sensitive to heat. They have achieved the complete inactivation of microbes at $60{ }^{\circ} \mathrm{C}$ as compare to sonication method and found the significant reduction in total plate count. Their results showed that the combined effect of ultrasonication and heat reduced the adverse changes in the food and also has the increased level of microbial inactivation of apple juice.

Table-6: Comparison of means \pm SE (Days $x$ Variety) for antioxidant activity (AA) ( $\mu$ g ascorbic acid/g)

\begin{tabular}{|c|c|c|c|c|c|}
\hline \multirow{2}{*}{ Days } & \multicolumn{4}{|c|}{ Variety } & Means \\
\cline { 2 - 6 } & Musambi & Succari & Feutrell's Early & Kinnow & Days x Variety \\
\hline 0 Day & $884.72 \pm 31.15 \mathrm{D}$ & $662.96 \pm 13.54 \mathrm{G}$ & $580.57 \pm 11.89 \mathrm{HI}$ & $1,072.76 \pm 15.40 \mathrm{~A}$ & $800.25 \pm 16.46 \mathrm{~A}$ \\
\hline 45 Days & $817.29 \pm 37.22 \mathrm{GE}$ & $608.34 \pm 18.32 \mathrm{H}$ & $529.99 \pm 15.92 \mathrm{~J}$ & $1,017.79 \pm 19.97 \mathrm{~B}$ & $743.35 \pm 16.84 \mathrm{~B}$ \\
\hline 90 Days & $757.83 \pm 43.36 \mathrm{~F}$ & $554.53 \pm 24.86 \mathrm{~J}$ & $478.61 \pm 22.32 \mathrm{~K}$ & $963.81 \pm 26.89 \mathrm{C}$ & $688.70 \pm 17.68 \mathrm{C}$ \\
\hline Means & $819.95 \pm 22.44 \mathrm{~B}$ & $608.61 \pm 12.59 \mathrm{C}$ & $529.73 \pm 11.32 \mathrm{D}$ & $1,018.12 \pm 13.51 \mathrm{~A}$ & \\
\hline
\end{tabular}

Means having similar letters in a column or in a row are statistically non-significant $(\mathrm{P}>0.05)$. Within box means express interaction means.

Table-7: Comparison of means \pm SE (Treatment $x$ Variety) for antioxidant activity (AA) ( $\mu$ g ascorbic acid/g)

\begin{tabular}{|c|c|c|c|c|c|}
\hline \multirow{2}{*}{ Treat. } & \multicolumn{3}{|c|}{ Variety } & \multicolumn{2}{c|}{ Means } \\
\cline { 2 - 6 } & Musambi & Succari & Feutrell's Early & Kinnow & Treat x Variety \\
\hline T0 & $676.86 \pm 43.89 \mathrm{~F}-\mathrm{H}$ & $522.52 \pm 35.36 \mathrm{~L}-\mathrm{N}$ & $456.91 \pm 34.65 \mathrm{MN}$ & $929.61 \pm 38.10 \mathrm{D}$ & $646.47 \pm 23.89 \mathrm{D}$ \\
\hline T1 & $806.83 \pm 14.46 \mathrm{E}$ & $621.36 \pm 12.78 \mathrm{H}-\mathrm{J}$ & $554.84 \pm 10.96 \mathrm{~J}-\mathrm{L}$ & $1,038.71 \pm 14.09 \mathrm{BC}$ & $755.44 \pm 21.67 \mathrm{~B}$ \\
\hline T2 & $665.36 \pm 29.00 \mathrm{G}-\mathrm{I}$ & $525.44 \pm 24.67 \mathrm{~K}-\mathrm{M}$ & $454.63 \pm 21.32 \mathrm{~N}$ & $931.04 \pm 26.39 \mathrm{D}$ & $644.12 \pm 22.59 \mathrm{D}$ \\
\hline T3 & $744.31 \pm 11.41 \mathrm{EF}$ & $593.18 \pm 10.18 \mathrm{JK}$ & $504.32 \pm 11.68 \mathrm{~L}-\mathrm{N}$ & $995.42 \pm 15.24 \mathrm{CD}$ & $709.31 \pm 21.86 \mathrm{C}$ \\
\hline T4 & $1,002.80 \pm 24.06 \mathrm{C}$ & $702.20 \pm 9.38 \mathrm{FG}$ & $601.35 \pm 8.96 \mathrm{IJ}$ & $1,103.20 \pm 9.94 \mathrm{AB}$ & $852.39 \pm 23.83 \mathrm{~A}$ \\
\hline T5 & $1,023.51 \pm 26.25 \mathrm{C}$ & $686.98 \pm 19.61 \mathrm{~F}-\mathrm{H}$ & $606.31 \pm 14.14 \mathrm{IJ}$ & $1,110.74 \pm 23.67 \mathrm{~A}$ & $856.89 \pm 25.19 \mathrm{~A}$ \\
\hline
\end{tabular}

Means having similar letters in a column or in a row are statistically non-significant $(\mathrm{P}>0.05)$. Within box means express interaction means.

$T_{0}=$ Control (citrus juice), $T_{1}=$ preservative juice $(0.075 \% \mathrm{KMS}), T_{2}=$ Pasteurization $81{ }^{\circ} \mathrm{C}$ for $90 \mathrm{sec}, T_{3}=$ preservative $(0.075 \%$ KMS) \& $90 \mathrm{sec}$ Pasteurization $81^{\circ} \mathrm{C}, T_{4}=04$ mints Ultrasound \& $90 \mathrm{sec}$ Pasteurization $81^{\circ} \mathrm{C}, T_{5}=04$ mints Ultrasound 
Muhammad Bilal Shahid et al.

Table-8: Comparison of means \pm SE (Days $x$ Variety) for total plate count $(T-P-C)(\log 10 \mathrm{cfu} / \mathrm{mL}$ )

\begin{tabular}{|c|c|c|c|c|c|}
\hline \multirow{2}{*}{ Days } & \multicolumn{4}{|c|}{ Variety } & Means \\
\cline { 2 - 6 } & Musambi & Succari & Feutrell's Early & Kinnow & Days x Variety \\
\hline 0 Day & $1.46 \pm 0.030 \mathrm{H}$ & $1.52 \pm 0.030 \mathrm{G}$ & $1.68 \pm 0.024 \mathrm{E}$ & $1.67 \pm 0.020 \mathrm{E}$ & $1.58 \pm 0.011 \mathrm{C}$ \\
\hline 45 Days & $1.62 \pm 0.056 \mathrm{~F}$ & $1.70 \pm 0.054 \mathrm{E}$ & $1.82 \pm 0.047 \mathrm{C}$ & $1.83 \pm 0.044 \mathrm{C}$ & $1.74 \pm 0.018 \mathrm{~B}$ \\
\hline 90 Days & $1.77 \pm 0.079 \mathrm{D}$ & $1.87 \pm 0.078 \mathrm{~B}$ & $1.97 \pm 0.071 \mathrm{~A}$ & $2.01 \pm 0.073 \mathrm{~A}$ & $1.91 \pm 0.025 \mathrm{~A}$ \\
\hline Means & $1.62 \pm 0.038 \mathrm{D}$ & $1.69 \pm 0.038 \mathrm{C}$ & $1.82 \pm 0.033 \mathrm{~B}$ & $1.84 \pm 0.034 \mathrm{~A}$ & \\
\hline
\end{tabular}

Means having similar letters in a column or in a row are statistically non-significant $(\mathrm{P}>0.05)$. Within box means express interaction means.

\section{Conclusion}

Thermo-sonication elicited better retention of total phenolic contents and total antioxidant activity without any significant impact on titratable acidity of citrus juices in comparison to the pasteurized and chemically preserved citrus juices. Additionally, thermo-sonication showed significant reduction in total plate count. These results proposed that thermosonication technique may effectively be used for the processing of citrus juices with improved functional properties.

\section{Disclaimer: None.}

Conflict of Interest: None.

Source of Funding: None.

\section{References}

Abid M, Jabbar S, Hu B, Hashim MM, Wu T, Lei S, Khan MA and Zeng X, 2015. Thermosonication as a potential quality enhancement technique of apple juice. Ultrason. Sonochem. 21(3): 984-990.

AOAC, 2012. International official Methods of Analysis. Method. 996.01.

Awad T, Moharram H, Shaltout O, Asker D and Youssef M, 2012. Applications of ultrasound in analysis, processing and quality control of food: A review. Int. Food Res. J. 48(2): 410- 427.

Bhat R, Kamaruddin NSBC, Min-Tze L and Karim A, 2011. Sonication improves kasturi lime (Citrus microcarpa) juice quality. Ultrason. Sonochem, 18(6): 1295-1300.

Borenstein B and Bunnell R, 1966. Carotenoids: Properties, occurrence, and utilization in foods. In: Adv. Food Res. pp. 195-276.

Cheng G, 2008. Procedures For Analysis of Citrus Products. 5th ed. John Bean Technologies Corporation, Inc. JBT Food Tech, Citrus Systems 400 Fairway Avenue, Lakeland, Florida 33801 U.S.A. pp. 3-4.
Dede S, Alpas H and Bayındirlı A, 2007. High hydrostatic pressure treatment and storage of carro and tomato juices: Antioxidant activity and microbial safety. J. Sci. Food Agric. 87(5):773782.

Fratianni A, Cinquanta L and Panfili G, 2010. Degradation of carotenoids in orange juice during microwave heating. LWT-Food Sci. Techol. 43(6): 867-871.

Igual M, García-Martínez E, Camacho $\mathrm{M}$ and Martínez-Navarrete N, 2011. Changes in flavonoid content of grapefruit juice caused by thermal treatment and storage. Innov. Food Sci. Emerg. Technol. 12(2): 153-162.

Karimi E, Oskoueian E, Hendra R, Oskoueian A and Jaafar HZ 2012. Phenolic compounds characterization and biological activities of citrus aurantium bloom. Mol. 17(2): 1203-1218.

Kaur G and Aggarwal P, 2015. Effect of chemical preservation over thermal processing on storage stability of tomato juice. Asian J. Dairy Food Res. 34(1): 49-53.

Khan A, Imran R, Siddique M, Mazzafer H and Khan M, 2004. New dimensions of Citriculture. Proceeding of international conference on Citriculture. Pub. Hort. Found. Pak. pp. 2426.

Khosa M.K, Hussain A, Riaz H, Aslam K, Chatha S and Zia K, 2011. Spectrophotometric quantification of antioxidant phytochemicals in juices from four different varieties of citrus limon, indigenous to Pakistan. J. Chem. Soc. Pak. 33(2): 188-192.

Kreutzmann S, Christensen LP and Edelenbos M, 2008. Investigation of bitterness in carrots (daucus carota 1.) based on quantitative chemical and sensory analyses. LWT-Food Sci. Technol. 41(2): 193-205.

Lessin WJ, Catigani GL and Schwartz SJ, 1997. Quantification of cis-trans isomers of provitamin a carotenoids in fresh and processed fruits and 
vegetables. J. Agric. Food Chem. 45(10): 37283732.

Louche LMM, Luro F, Gaydou EM and Lesage JC, 2000. Phlorin screening in various citrus species and varieties. J. Agric. Food Chem. 48(10): 4728-4733.

Naczk M and Shahidi F, 2003. Phenolic compounds in plant foods: Chemistry and health benefits. Food Sci. Nutr. 8(2): 200-218.

Nadeem M, Ubaid N, Qureshi TM, Munir M and Mehmood A, 2018. Effect of ultrasound and chemical treatment on total phenol, flavonoids and antioxidant properties on carrot-grape juice blend during storage. Ultrason. Sonochem. 45: 16.

Patist A and Bates D, 2008. Ultrasonic innovations in the food industry: From the laboratory to commercial production. Innov Food Sci Emerg Technol. 9(2): 147-154.

Pereira R and Vicente A, 2010. Environmental impact of novel thermal and non-thermal technologies in food processing. Int. Food Res. J. 43(7): 1936-1943.

Prieto P, Pineda M and Aguilar M, 1999. Spectrophotometric quantitation of antioxidant capacity through the formation of a phosphomolybdenum complex: Specific application to the determination of vitamin e. Anal. Biochem. 269(2): 337-341.

Purcell AE, Walter Jr WM and Thompkins WT, 1969. Relation of vegetable color to physical state of the carotenes. J. Agric. Food Chem. 17(1): 41-42.

Qureshi TM, Nadeem M, Maken F, Tayyaba A, Majeed $\mathrm{H}$ and Munir M, 2020. Influence of ultrasound on the functional characteristics of indigenous varieties of mango (mangifera indica 1.). Ultrason. Sonochem. 64: 104987.

Ren JN, Tai YN, Dong M, Shao JH, Yang SZ, Pan SY and Fan G, 2015. Characterisation of free and bound volatile compounds from six different varieties of citrus fruits. Food Chem. 185: 25-32.
Rocha A and Morais A, 2003. Shelf life of minimally processed apple (cv. Jonagored) determined by colour changes. Food Contr. 14(1): 13-20.

Rockville $M$ and Latimer GW, 2016. Official methods of analysis of AOAC International. Official methods of analysis of AOAC international.

Rutledge P, 1996. Production of non-fermented fruit products. In Fruit processing. Springer. pp. 7096.

Scalzo RL, Iannoccari T, Summa C, Morelli R and Rapisarda P, 2004. Effect of thermal treatments on antioxidant and antiradical activity of blood orange juice. Food Chem. 85(1): 41-47.

Singleton VL, Orthofer R and Lamuela-Raventos RM, 1999. Analysis of total phenols and other oxidation substrates and antioxidants by means of Folin-Ciocalteu reagent. Methods Enzymol. 299: 152-178.

Zhang Q, Tan S, McKay A and Yan G, 2005. Carrot browning on simulated market shelf and during cold storage. J. Sci. Food Agric. 85(1): 16-20.

Zou Y and Jiang A, 2016. Effect of ultrasound treatment on quality and microbial load of carrot juice. Food Sci. Technol. 36(1): 111-115.

\section{Contribution of Authors}

Shahid MB \& Nadeem M: Conceptualized the study, designed research methodology, analysed data and wrote original draft and approved final draft

Murtaza MA: Helped in laboratory analysis, reviewed literature and approved the final draft Rukh L: Data analysis and interpretation Shaukat A: Performed laboratory analysis and reviewed literature

Riaz MN: Contributed in article write up and editing 